\title{
Sustainable Development Indicators in Poland: Measurement and System Evaluation
}

\author{
Maria Urbaniec
}

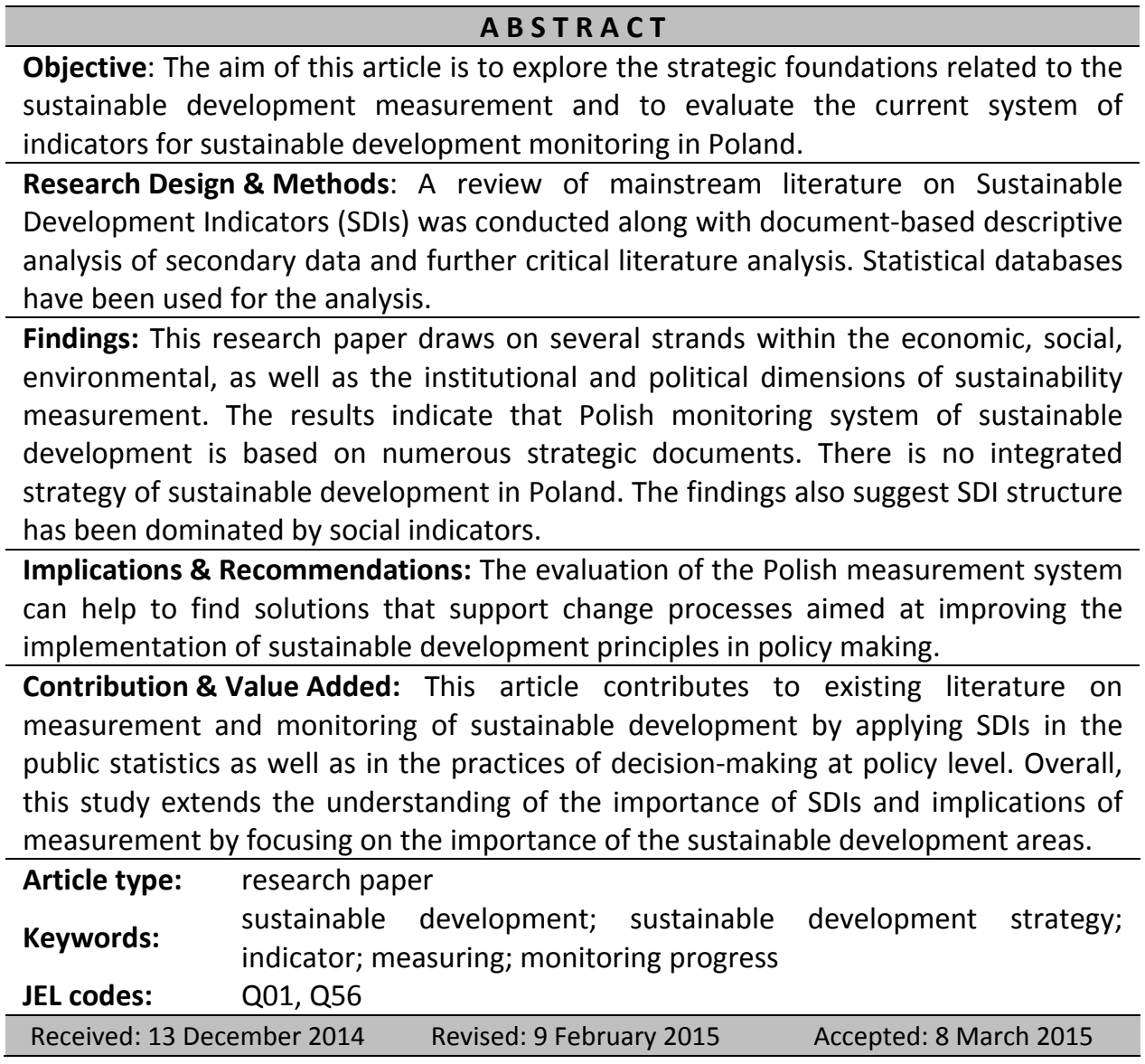

\section{Suggested citation:}

Urbaniec, M. (2015). Sustainable Development Indicators in Poland: Measurement and System Evaluation. Entrepreneurial Business and Economics Review, 3(1): 119-134, DOI: http://dx.doi.org/10.15678/EBER.2015.030109. 


\section{INTRODUCTION}

Sustainable development is one of the most important challenges of the modern world, perceived also as a key trend of global environmental policy and socio-economic development (Famielec, 2009, pp. 39-41; European Union, 2013b, p. 30). The definition of Sustainable Development was put forth for the first time in the Bruntland report "Our Common Future" (World Commission on Environment and Development, 1987), and later in the Declaration of the United Nations Conference on Environment and Development of 14 June 1992 (United Nations, 1992). In line with this, sustainable development is defined as one that seeks to meet the needs of the present generation without compromising the ability to meet the needs of future generations. (World Commission on Environment and Development, 1987, p. 37).

The overarching objective of sustainable development is to integrate economic, social and environmental policies at the local, regional and global levels (Ministerstwo Środowiska, 1999, pp. 15-17; Fiedor, 2013, pp. 10-11; Ghosh \& Goswami, 2014). Implementation of sustainable development is related to a fundamental change in how to proceed, taking into account the integrated interdisciplinary approach (Urbaniec \& Halavach, 2008; Borys, 2011, pp. 75-81). The need to change the current model of economic development to a more sustainable one has also been recognized as one of the priority areas by the United Nations (UN), the Organization for Economic Cooperation and Development (OECD) and the EU (Urbaniec, 2011, pp. 291-294; OECD, 2012; United Nations, 2012).

At the EU level, an important role in the implementation of sustainable development is played by the Strategy for Sustainable Development of the European Union, approved in May 2001 by the European Council in Gothenburg, and then renewed in June 2006 (Council of the European Union, 2006). It specifies the desired directions of social, economic and environmental changes in the long term, as well as how to achieve them. To support this development, the strategy "Europe 2020 A strategy for smart, sustainable and inclusive growth" was adopted by the European Commission in 2010. It includes three interrelated priorities; smart growth (based on knowledge and innovation), inclusive growth (fostering a high-employment economy), and sustainable development, which aims at reinforcing a more resource efficient and more competitive economy (European Commission, 2010; Jäger, 2009, pp. 5-11).

Taking action towards sustainable development requires a coordinated set of participatory processes that enable the analysis improvement, capacity strengthening, planning and investments. They are designed to integrate short- and long-term economic, social and environmental society through a mutually supporting action. To meet the challenges of sustainable development, strategic planning practices should be more effective, efficient, credible and durable.

The development and implementation of framework conditions that promote sustainable development requires a deep understanding of the economic, social, environmental synergies. Adequate information to support the analysis of the political action and the monitoring progress (Borys \& Fiedor, 2008, pp. 121-122; Czaja, 2009, pp. 191-193; Levin \& Clark, 2010, p. 40) also plays an important role in this context. A set of Sustainable Development Indicators (SDI), defined by Eurostat, which include the data 
from EU member countries (European Commission, 2014) is used for monitoring the objectives implementation of the EU Sustainable Development Strategy. Reliable empirical and statistical data are needed to measure the progress and evaluate the effectiveness of policies and programs, not only in the EU but also in each country, especially in the context of the "Europe 2020" Strategy (European Union, 2013a, p. 12). Effective policies in these areas require statistical information from different disciplines (European Union, 2013a, p. 21).

On this basis, it is hypothesized that the monitoring of sustainable development is a strategic process of implementation of sustainable development and requires continuous measurement and control of the results. In this context, it is important not only the subject of monitoring, expressed in the strategic objectives, but also the measurement tools, including appropriate structure indicators.

The aim of this article is to explore the strategic foundations related to the sustainable development measurement as well as to evaluate the current system of indicators for sustainable development monitoring in Poland. The main research questions are; firstly, what is the state of the art regarding the measurement of sustainable development in Poland and, secondly, what issues play a key role in the monitoring system. The paper highlights the importance of and relevant practices related to the SDI system and to the measurement structure in Poland. It also focuses on the identification of measurement areas as well as on the evaluation of the indicators system supporting the implementation of the concept of sustainability. There has been no research study on sustainability measurement that addresses the above research concerns.

The paper starts with presenting the strategic approach to sustainable development at the policy level as well as the principles of its measurement in Poland. Based on this theoretical framework, the data used in the analysis has been described and the foundation of the methodological approach to the measurement system has been introduced. Conclusions include the main results on the importance of SDI in terms of structure, taking into account the dimensions, main themes and subthemes. This will allow one to evaluate the progress in developing a system for measuring and monitoring sustainable development in a synthetic manner. The last section concludes the paper with the discussion of the findings. A critical evaluation of the monitoring system has been carried out. The evaluation of the current SDI framework as well as its measurement system in Poland contributes to the identification of the main strengths and weaknesses of the implementation of sustainable development.

\section{LITERATURE REVIEW}

\section{Strategic Foundations of Sustainable Development in Poland}

The Polish commitment to implement the principles of sustainable development was not only a result of the participation in the United Nations Conference "Environment and Development", but also of the signing of key documents, such as The Rio Declaration on Environment and Development, the Agenda 21 - Global Programme of Action on Sustainable Development (Ministerstwo Środowiska, 1999). The State committed itself to the implementation of sustainable development policy both for present and future 
generations, through the creation of sustainable communities being able to govern and use resources efficiently and to draw the ecological and social innovation potential of the economy, ensuring prosperity, environmental protection and social cohesion.

In Poland the sustainable development concept has been recognized as a constitutional principle. According to Article 5 of the Constitution of the Republic of Poland, dated 2 April 1997, "the Republic of Poland shall safeguard the independence and integrity of its territory and ensure the freedoms and rights of persons and citizens, the security of the citizens, safeguard the national heritage and shall ensure the protection of the natural environment pursuant to the principles of sustainable development" (Konstytucja Rzeczypospolitej Polskiej, 1997, art. 5).

The Law on Environmental Protection of 27 April 2001 completes the constitutional principle of sustainable development in Poland. In this act the concept of sustainable development is defined in article 3 point 50 of the Law, according to which: "Sustainable development is understood as such a socio-economic development in which the process of integrating political, economic and social actions occurs taking into account the natural balance and stability of basic natural processes in order to guarantee the possibilities of fulfilling basic needs of separate societies or citizens not only of the contemporary generation, but future generations as well" (Ustawa z dnia 27 kwietnia 2001 r. Prawo ochrony środowiska, art. 3 pkt. 50).

Furthermore, the concept of sustainable development is also found in other legal acts, including the act dated 27 March 2003, i.e. the Law on Planning and Spatial Development. In line with this, the spatial order and sustainable development are accepted as a basis for actions in the field of shaping the spatial policy, and when preparing the concept of spatial development the national rules of sustainable development are taken into account basing on natural, cultural, social and economic conditions (Ustawa z dnia 27 marca 2003 r. o planowaniu i zagospodarowaniu przestrzennym, art. 1).

Another legal act relating to sustainable development is the Law on Development Policy Principles dated 6 December 2006. The term 'development policy' is defined 'as a complex of mutually connected activities undertaken and realized in order to ensure a stable and sustainable development of the national, socioeconomic, regional and spatial cohesion, raising competitiveness of the economy and creating new workplaces on a national, regional or local scale" (Ustawa z dnia 6 grudnia 2006 r. o zasadach prowadzenia polityki rozwoju, art. 2). According to that, sustainable development is only one of the areas of the cohesion policy implemented on the basis of development policy through operational programs which have established measures aimed at achieving the objectives at all levels of public administration (Central Statistical Office, 2014b).

Other strategic documents which play an important role in creating goals and priorities connected with the long-term development of the country in line with the sustainable development principle are:

- "The National Development Strategy 2020. Active society, competitive economy, efficient state", an update of the National Development Strategy 2007-2015, accepted by the Council of Ministers on 25 September 2012 (Council of Ministers, 2012)

- "Poland 2030. Development Challenges" (Boni, 2009), 
- The Long-term National Development Strategy "Poland 2030. The Third Wave of Modernity", accepted by the Council of Ministers on 5 February 2013 (Ministerstwo Administracji i Cyfryzacji, 2013).

- Moreover, the concept of sustainable development has appeared in many strategies, policies and sector programs as well as other strategic documents, e.g. (Central Statistical Office, 2011, p. 13):

- "National Environmental Policy for 2009-2012 and its 2016 Outlook",

- "Poland's Climate Policy - the Strategies for Greenhouse Gas Emission Reductions in Poland until 2020",

- "Energy Policy of Poland until 2030",

- "Strategy of Changing Production and Consumption Patterns to Favour the Implementation of Sustainable Development Principles",

- "National Transport Policy for 2006-2025".

Due to the numerous strategic documents in this field, the Council of Ministers accepted the document "Plan of putting in order development strategies" on 24 November 2009 (Ministerstwo Rozwoju Regionalnego, 2012). This Plan was intended to unify obligatory strategic documents and limit the number of obligatory strategies to 9 new integrated development strategies (out of 42 existing strategies), basing on the diagnosis and recommendations resulting from the report "Poland 2030. Development Challenges". The new integrated strategies include (Ministerstwo Rozwoju Regionalnego, 2012, pp. 4-12):

- Strategy of Innovativeness and Effectiveness of the Economy,

- Human Capital Development Strategy,

- Transport Development Strategy,

- Strategy for Energy Security and the Environment,

- Efficient State Strategy,

- Social Capital Development Strategy,

- National Strategy of Regional Development 2010-2020: Regions, Cities, Rural Areas,

- Sustainable Development Strategy of Rural Areas, Agriculture and Fishing,

- Strategy for Development of the National Security System.

On this basis, it can be concluded that the strategic priorities of sustainable development are reflected in many documents. The above-mentioned strategies are targeted at development goals by supporting the implementation of the long-term national development strategy, taking into consideration a social, economic and ecological cohesion.

Nevertheless, there is a lack of a separate strategy for sustainable development of Poland. Although a document called the "Polish Sustainable Development Strategy 2025" was developed by the Ministry of Environment as early as 1999, it contained only guidelines for ministries developing sector strategies and recommendations of actions for sustainable development (Ministerstwo Środowiska, 1999). This document contained neither measurable goals nor indicators. To be able to assess how such a broad spectrum of strategic documents plays an important role in the implementation of sustainable development, the theoretical framework of the measurement system should first be presented. 


\section{Theoretical Framework of Sustainable Development Indicators}

The sustainable development indicators are the main tool for monitoring progress in the implementation of the new development paradigm (Sustainable Development Solutions Network, 2014, p. 7). In the literature there are different definitions of "an indicator". The term "indicator" is defined as an aggregate measurement, connected with an important issue or phenomenon and performed on the basis of a series of observed facts. Indicators can be used to determine a relative item, or to indicate a positive or negative change. According to Eurostat, the statistical indicator shows the statistical data for a specific time, place, or other relevant characteristics, adjusted in at least one dimension (usually size), in order to enable comparisons (European Union, 2013a, p. 20). In general, "indicator" and "measure" are terms used alternatively (Borys, 2005, p. 62). The most important feature of an indicator is its comparability (as opposed to the characteristics generally expressed in absolute values), which enables ranking of the compared object with other objects (Central Statistical Office, 2011, p. 15; Sekerka, Obrsalova \& Bata, 2014, p. 223).

The development of a SDI system is a relatively complex issue, because it is associated with a broad spectrum of sustainability, with the requirements of simplicity and ease of indicators applicability. In the literature there are different approaches to the indicator system (Preisner \& Pindór, 1999, pp. 9-12; Parris \& Kates, 2003, pp. 559586; Atkinson \& Dietz, 2007, pp. 45-47; Śleszyński, 2013, pp. 144-160). According to Śleszyński (2011) the SDIs should address the global problems of national economies, sectors, specific segments, areas of environmental protection and local communities. Furthermore, it should be added that the implementation of sustainable development should involve all the important issues related to human functioning: economic, social, cultural, natural, spatial and institutional. A creation of such a comprehensive system of indicators hinders its practical application.

The primary role of indicators of sustainable development is the operationalization of sustainable development for the monitoring of various planning documents developed at the local, regional and national level by specifying for each level a welldefined set of indicators (Borys, 2005, pp. 62-63; Levin \& Clark, 2010, pp. 40-41). Indicators usually contribute directly to the strategic areas of the EU policy and global policy, because they are used for setting objectives and monitoring their implementation (Burchard-Dziubińska, 2014, pp. 23-30). Same indicators do not always cover all aspects of the development and change, but contribute to their explanation. They enable the comparison at a specified time, e.g. of countries and regions, and thereby they support the decision-making process (Parris \& Kates, 2003, pp. 559-560).

The measurement of progress is also an integral part of the EU Sustainable Development Strategy (Ciżmowska, 2012, p. 57). It takes place on the basis of a set of SDIs, developed by the European Commission in cooperation with the Member States, EFTA (European Free Trade Association) and candidate countries. Eurostat plays a leading role in their development and monitoring in the EU, as it is responsible for the development of indicators of sustainable development and its measurement, as well as for publishing reports every two years (European Union, 2013b, p. 20). In order to provide a methodological coherence and comparability between countries, the 
calculation of the indicators is carried out by Eurostat, based on primary data from national statistics (European Union, 2013a, p. 12). Therefore, in some cases differences may occur between the indicators provided by each country, and those presented in the Eurostat database. Monitoring is an essential element of the implementation of the strategy, including processes (e.g. the quality and scope of participation and information systems), effects, and possible changes in the measurement base line. It requires an approach in which the process and outcome indicators will be established the same time as the visions and goals (OECD, 2001, p. 18). Most OECD countries have introduced a set of indicators corresponding to national strategies. These indicators vary from country to country and are generally organized according to specific themes and subthemes (OECD, 2006, p. 28).

In Poland sustainable development is monitored in two ways. On one hand, it is monitored within the "System monitoring developments" in relation to the cohesion policy and the development policy, especially in accordance with the applicable strategies in Poland (at national, supra-regional and voivodship levels) and in the European Union (Strategy "Europe 2020"). It is applied only to promote the resourceefficient and cost-effective economy, more competitive and environmentally friendly, including such areas as: adaptation to climate change, prevention of risks and risk management, low-carbon economy, environmental protection and resource efficiency (Central Statistical Office, 2014b). On the other hand, despite the lack of a separate Polish strategy for sustainable development, the data base "Indicators of sustainable development" related to the methodology of Eurostat is currently being established by the Central Statistical Office. Further analysis will focus on that measurement approach.

\section{MATERIAL AND METHODS}

For this purpose, the method of descriptive analysis of secondary data has been followed (documents test method, literature analysis and critique). Based on the analysis of existing data, the key strategic documents and statistical information related to Poland have been reviewed. Among the analyzed documents the following ones should be mentioned: (1) general strategic documents of development policy, (2) statistical data, including database of the Central Statistical Office (3) key EU and international documents, e.g. the strategy "Europe 2020", the priorities of the Organization for Economic Cooperation and Development (OECD) and the United Nations (UN), which determine the development directions of Poland.

While the analysis of the sustainable development is a popular topic in the existing body of literature, many questions about these issues, especially of measurement in Poland, remain unanswered. The paper focuses on the identification of measurement areas and relevant practices related to sustainable development. The current SDIs supporting the implementation of sustainability has been evaluated. For this purpose, four dimensions of SDIs (social, economic, environmental, institutional and political) and their operationalization in the Polish measurement system of SD has been explored. Using the data from statistical institutions, the number of indicators with respect to the dimensions and theme-oriented framework has been examined. Moreover, the importance of themes can be identified, assuming that the greater number of indicators 
within each analyzed theme, signifies a higher rank of this field, as more important themes gain more attention and interest of policy makers.

In Poland, the Central Statistical Office is responsible for the monitoring of sustainable development. So activities in the field of SDIs for Poland are carried out in accordance with the public statistics. The data for the sustainable development database by Eurostat are compiled by a few institutions, first of all: Central Statistical Office and Regional Statistical Offices, Ministry of the Environment, Ministry of Finance, National Bank of Poland, Chief Inspectorate of Environmental Protection and Main Inspectorate of Agricultural and Food Quality (Central Statistical Office, 2011, p. 9). Under the agreement between the European Commission and the Central Statistical Office, a set of SDIs for Poland has been implemented.

Sustainable development monitoring is based on the new paradigm of development by identifying (Central Statistical Office, 2011, p. 15):

- the principles of development, being a basic 'filter' for the selection of indicators,

- the goals which are the positive target states of development, as presented in different planning documents,

- dimensions: social, economic, environmental, institutional and political.

Figure 1 below illustrates the interrelationships between categories fundamental for the correct measurement of sustainable development.

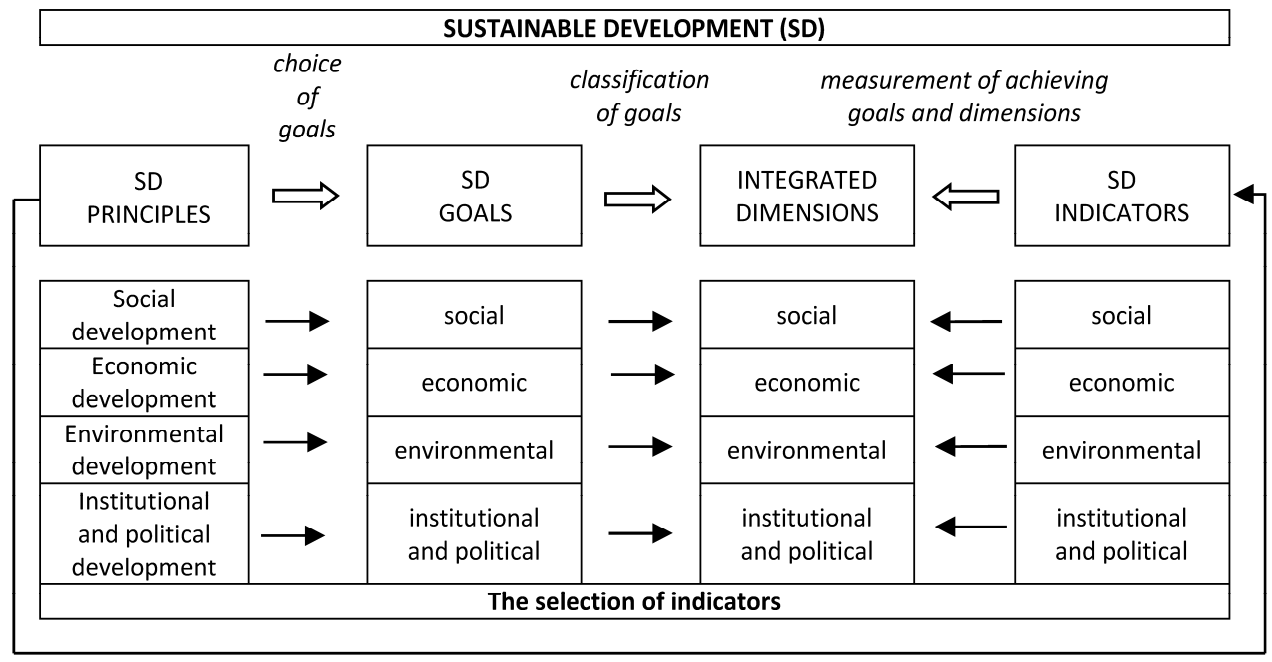

Figure 1. Construction and classification of national sustainable development indicators Source: own elaboration based on (Central Statistical Office, 2011, p. 16).

Sustainable development indicators used to monitor sustainable development in Poland refer to the ten thematic areas (Table 1). Most of these are comparable with those of the Eurostat methodology for assessment of the EU SDI Framework, which is used to monitor the EU Sustainable Development Strategy.

The monitoring of EU Sustainable Development Strategy is based on more than 100 indicators, out of which three groups of indicators are specified. The most significant are 
the headline indicators, which depict an overview of the progress of the EU on the path to sustainable development regarding the objectives and tasks provided in the Strategy (United Nations, 2008, pp. 36-37). The operational indicators as well as the explanatory indicators, which supplement the main indicators within a given thematic area can also be analyzed to obtain a fuller picture. The set of SDIs also includes a group of contextual indicators. They are not used directly for monitoring the objectives of the strategy. They are difficult to interpret in a normative manner, but provide valuable background information for the phenomena directly related to sustainable development, and can be useful for analytical purposes. A complete list of SDIs is published on the website of Eurostat in the bookmark "Selected statistics - Sustainable development indicators" (European Commission, 2014b).

Table 1. The main themes of SDI system in Poland and EU

\begin{tabular}{|l|l|l|}
\hline \multicolumn{1}{|c|}{ SD Dimensions } & \multicolumn{1}{|c|}{ Themes of SDI in Poland } & \multicolumn{1}{c|}{ Themes of SDI in EU } \\
\hline \multirow{5}{*}{ Social } & Public safety & - \\
\cline { 2 - 3 } & Social inclusion & Social inclusion \\
\cline { 2 - 3 } & Public health & Public health \\
\cline { 2 - 3 } & Demographic changes & Demographic changes \\
\cline { 2 - 3 } & $\begin{array}{l}\text { Sustainable consumption and } \\
\text { production }\end{array}$ & - \\
\hline Economic & $\begin{array}{l}\text { Economic and social } \\
\text { development }\end{array}$ & Socio-economic development \\
\cline { 2 - 3 } & $\begin{array}{l}\text { Sustainable consumption and } \\
\text { production }\end{array}$ & $\begin{array}{l}\text { Sustainable consumption and } \\
\text { production }\end{array}$ \\
\cline { 2 - 3 } & Sustainable transport & Sustainable transport \\
\hline Environmental & Natural resources & Natural resources \\
\cline { 2 - 3 } & Climate change and energy & Climate change and energy \\
\cline { 2 - 3 } & $\begin{array}{l}\text { Sustainable consumption and } \\
\text { production }\end{array}$ & - \\
\hline Institutional and political & Good governance & Good governance \\
\cline { 2 - 3 } & - & Global partnership \\
\hline
\end{tabular}

Source: own elaboration based on (Central Statistical Office, 2014a) and (European Union, 2013b, p. 20).

The Polish classification of indicators does not contain such an advanced division into the headline indicators, operational indicators, contextual indicators (European Communities, 2009, p. 34). Despite the fact that the SDI framework in Poland is based on the Eurostat methodology, it shows significant differences in the indicators structure. The Polish system only covers the operational indicators relating to the key thematic areas. The set of SDIs is listed on the website of the Central Statistical Office, the Regional Data Bank, in the bookmark "Sustainable Development Indicators - a regional unit" (Central Statistical Office, 2014a). Ultimately, the set of SDIs for Poland contains a total of 74 indicators that refer to the dimensions of sustainable development and thematic areas. On this basis it is possible to synthesize the progress in establishing a monitoring system for the measurement of sustainable development. 


\section{RESULTS AND DISCUSSION}

The Polish SDI system can be evaluated with regard to various aspects. Taking into account the direction of the implementation of sustainable development, one can analyze the importance of indicators with regard to the size and thematic areas which have been monitored by operational indicators since 2004.

Considering the category of "dimension", the SDIs refer to the following dimensions (European Communities, 2009, p. 33):

- social dimension - indicators on improving quality of life of society,

- economic dimension - indicators for effective socio-economic development,

- environmental dimension - indicators related to the conservation and rational shaping of the natural environment,

- institutional and political dimensions - indicators covering the challenges of a global partnership and good governance.

All these dimensions constitute an integrated approach to sustainable development, including social, economic and environmental phenomena, and based on ethics and morality.

Regarding the importance of SDIs, the analysis revealed that most indicators have been developed for the social dimension (33). There are significantly fewer indicators for the economic dimension (18) and the environmental dimension (15), and the lowest number exists for the institutional and political dimension (8) (Table 2). The overwhelming predominance of the social dimension in terms of the number of indicators may indicate the main priority in the Polish development policy. However, it can be assumed that the dominance of one of the dimensions is not conducive to the implementation of an integrated approach to sustainable development in Poland.

The main themes in the structural division of the Sustainable Development Indicators in Poland in majority are consistent with the Eurostat methodology. The number of indicators distributed among the main themes is also unequal. By analyzing the number of Eurostat indicators by area, it can be observed that the leading role is played by the area of "social inclusion" (12) and "economic and social development" (8). The least important is "public safety" (3). It should also be noted that the theme "Sustainable consumption and production" is linked with social, economic and environmental governance and includes respectively different indicators resulting from different subthemes.

By analyzing the number of Eurostat indicators with regard to subthemes, it should be noted that most of the indicators operational aspect relates to "demographic changes" (5), "public health" (5) as well as "economic instruments" ${ }^{1}$ (5). It must be stressed that these sub themes also refer only to the guiding principles related to the social dimension and good governance. The least important role in the monitoring of sustainable development is played by such sub themes as: "road and traffic accidents",

\footnotetext{
${ }^{1}$ Economic instruments are here defined as a tool to promote sustainable development, which aims to prevent excessive load on the environment and to exert a stabilizing influence on government finances (e.g. the rational management of funds by local governments, the use of environmental fees (Central Statistical Office, 2014a).
} 
"fresh water resources", "climate changes" and "air protection", where the measurement is made by using only one operational indicator in each case.

Based on the Central Statistical Office methodology, the structure of sustainable development indicators enables the assessment of measurement of sustainable development by dimensions, themes and subthemes. It is clear that the number of indicators is unequally distributed among the dimensions, themes and subthemes. An analysis of the indicator structure reveals that the dominant role is played by the social dimension, and especially the area of "social inclusion", while a more detailed analysis of the number of the indicators by subthemes emphasizes the importance of "public health", "demographic changes" as well as "economic instruments". These indicators represent, both social as well as institutional and political dimensions. It must be noted that the set of SDIs is organized within a theme-oriented framework to provide a clear and easily communicable structure and relevance to political decision-making. The framework is flexible enough to adjust to possible changes in these priorities and objectives, bearing in mind that new issues and priorities emerge from time to time.

Table 2. The structure of sustainable development indicators (number of indicators)

\begin{tabular}{|c|c|c|}
\hline Dimensions & Themes & Subthemes \\
\hline \multirow[t]{10}{*}{ Social (33) } & \multirow[t]{2}{*}{ Public safety (3) } & Delinquency (2) \\
\hline & & Road traffic accidents (1) \\
\hline & \multirow[t]{3}{*}{ Social inclusion (12) } & Poverty and living conditions (4) \\
\hline & & Access to the labor market (4) \\
\hline & & Education (4) \\
\hline & \multirow[t]{2}{*}{ Public health (7) } & Public health (5) \\
\hline & & Health determinants (2) \\
\hline & \multirow[t]{2}{*}{ Demographic changes (7) } & Demographic changes (5) \\
\hline & & The adequacy of income in old age (2) \\
\hline & $\begin{array}{l}\text { Sustainable consumption } \\
\text { and production (4) }\end{array}$ & Consumption patterns (4) \\
\hline \multirow[t]{5}{*}{ Economic (18) } & \multirow{3}{*}{$\begin{array}{l}\text { Economic and social } \\
\text { development (10) }\end{array}$} & Economic development (3) \\
\hline & & Innovativeness (3) \\
\hline & & Employment (4) \\
\hline & $\begin{array}{l}\text { Sustainable consumption } \\
\text { and production (4) }\end{array}$ & Patterns of agricultural production (4) \\
\hline & Sustainable transport (4) & Transport (4) \\
\hline \multirow[t]{7}{*}{ Environmental (15) } & \multirow[t]{3}{*}{ Natural resources (7) } & Biodiversity (3) \\
\hline & & Freshwater resources (1) \\
\hline & & Land use (3) \\
\hline & \multirow{2}{*}{$\begin{array}{l}\text { Climate change and } \\
\text { energy (4) }\end{array}$} & Climate change (1) \\
\hline & & Energy (3) \\
\hline & \multirow{2}{*}{$\begin{array}{l}\text { Sustainable consumption } \\
\text { and production (4) }\end{array}$} & Waste management (3) \\
\hline & & Air protection (1) \\
\hline \multirow[t]{2}{*}{ Institutional and political (8) } & \multirow[t]{2}{*}{ Good governance (8) } & Openness and participation (3) \\
\hline & & Economic instruments (5) \\
\hline
\end{tabular}

Source: own elaboration based on (Central Statistical Office, 2014a). 
On this basis it is possible to identify the importance of topics, assuming that the greater the number of actions (indicators) for each of the analyzed topics the more important the area is in the current policy. This assumption is based on the argument that the structure and number of indicators reflect the current priorities of the government's policy.

\section{CONCLUSIONS}

The paper explores the strategic challenges of SDI implementation and evaluates the current measurement system. The analysis provides a critical assessment of the current state of knowledge in the field of measuring sustainable development and identifying the main weaknesses of the SDI system. The increasing importance of sustainability pushes for the creation of an effective measurement system, and thus the indicators to monitor progress in this area. This causes the change in the perception of sustainable development towards a full integration at the political level, especially in relation to the different strategic documents. In Poland, there is no separate strategy for sustainable development and thus many strategic documents set out the socio-economic objectives which have become the basis for the selection of indicators to monitor their realization. The process and the effects of their implementation are differentiated. Sustainable development is one of the areas of the Polish development policy, which is separately monitored in accordance with the new strategic documents and the strategy "Europe 2020". The study revealed that the Polish system of measurement is currently dependent on a number of documents, and this may hinder the monitoring of the sustainable development in Poland, as well as its implementation.

Therefore, the assessment of the Polish measurement system allows the conclusion that it is in the initial development phase. The current system of indicators indicates differences with respect to the system operated by Eurostat. The differences concern not only the quantity but also the structure of the system of indicators. The Polish classification takes into account the operational indicators with regard to themes and sub-themes, and does not include the division into headline indicators, operational indicators, contextual indicators, according to the Eurostat methodology.

In addition, the lack of strategy makes it difficult to assess whether and for what purposes indicators have already been achieved or will be in the near future, or what indicators measure should measure (or if indicators measure the set goals). To be able to assess the progress in the implementation of sustainable development, it is necessary to define the object of measurement, i.e. measurable objectives resulting from the national strategy of sustainable development. The current structure of the indicators with regard to the dimensions of sustainable development indicates that the social issues are a priority of the current policy. This can be deduced from the predominant number of indicators.

This article contributes to the existing literature on measurement and monitoring of sustainable development by applying SDIs in the public statistics as well as in the practices of decision-making at the policy level. Based on the statistical data for the presented indicators, it is necessary to provide an analytical discussion on the focus of the sustainable development progress in Poland. This work is limited to the evaluation of 
the statistical measurement system. A further detailed empirical research based on the evaluation of the progress is needed.

\section{REFERENCES}

Atkinson, G., \& Dietz, S. (2007). Progress in the measurement of sustainable development. In Encyclopaedia of Life Support Systems (Corp. Ed.) (pp. 195-222), Oxford, UK: United Nations Educational, Scientific and Cultural Organization.

Boni, M. (Ed.) (2009). Polska 2030. Wyzwania rozwojowe. Zespół Doradców Strategicznych Prezesa Rady Ministrów. Warszawa: Kancelaria Prezesa Rady Ministrów.

Borys, T. (2005). Podstawy metodyczne budowy wskaźników zrównoważonego rozwoju. In T. Borys (Ed.), Wskaźniki zrównoważonego rozwoju (pp. 62-114). Warszawa - Białystok: Wydawnictwo Ekonomia i Środowisko.

Borys, T. (2011). Zrównoważony rozwój - jak rozpoznać ład zintegrowany. Problemy Ekorozwoju Problems of Sustainable Development, 6(2), 75-81.

Borys, T., \& Fiedor, B. (2008). Operacjonalizacja i pomiar kategorii zrównoważonego rozwoju przyczynek do dyskusji. In M. Plich (Ed.), Rachunki narodowe. Wybrane problemy i przykłady zastosowań (pp. 115-131). Łódź: Uniwersytet Łódzki.

Burchard-Dziubińska, M. (2014). Idea zrównoważonego rozwoju. In M. Burchard-Dziubińska, A. Rzeńca, \& D. Drzazga (Eds.), Zrównoważony rozwój - naturalny wybór (pp. 9-34). Łódź: Wydawnictwo Uniwersytetu Łódzkiego.

Ciżmowska, A. (2012). Social Policy in the European Sustainable Development Strategy. Problemy Ekorozwoju - Problems of Sustainable Development, 7(2), 51-59.

Central Statistical Office (2011). Sustainable Development Indicators for Poland. Katowice: Statistical Office in Katowice.

Central Statistical Office (2014a). Bank Danych Lokalnych, Modut: Wskaźniki zrównoważonego rozwoju, Retrieved on November 15, 2014 from http://stat.gov.pl/bdl/app/strona.html?p_ name=indeks.

Central Statistical Office (2014b). [online] System monitorowania rozwoju. Retrieved on November 15, 2014 from: <http://strateg.stat.gov.pl>.

Commission of the European Communities (2009). Mainstreaming sustainable development into EU policies: 2009 Review of the European Union Strategy for Sustainable Development. $\operatorname{COM}(2009) 400$ final, Brussels.

Council of Ministers (2012). National Development Strategy 2020. Active Society, Competitive Economy, Efficient State. Attachment to Resolution No 157 of the Council of Ministers of 25 September 2012, Warsaw.

Council of the European Union (2006). Renewed EU Sustainable Development Strategy, 10917/06, Brussels.

Czaja, S. (2009). Informacja jako podstawa kształtowania zrównoważonego rozwoju i gospodarki opartej na wiedzy. In B. Poskrobko (Ed.), Zrównoważony rozwój gospodarki opartej na wiedzy (pp.190-207). Białystok: Wydawnictwo Wyższej Szkoły Ekonomicznej w Białymstoku.

European Commission (2010). Europe 2020. A strategy for smart, sustainable and inclusive growth. $\operatorname{COM}(2010)$ 2020, Brussels.

European Commission (2014). [online] Eurostat - Sustainable Development Indicators. Retrieved on November 15, 2014 from: <http://epp.eurostat.ec.europa.eu/portal/page/portal/ sdi/indicators $>$. 
European Communities (2009). Sustainable development in the European Union. 2009 monitoring report of the EU sustainable development strategy. Luxembourg.

European Union (2013a). Regulation (EU) No 99/2013 of the European Parliament and of the Council of 15 January 2013 on the European statistical programme 2013-17. Text with relevance for the EEA and for Switzerland. Council of the European Union, Official Journal of the European Union, L 39.

European Union (2013b). Sustainable development in the European Union. 2013 monitoring report of the EU sustainable development strategy. Luxembourg.

Famielec, J. (2009). Wpływ idei zrównoważonego rozwoju na politykę państwa i funkcjonowanie przedsiębiorstw. In B. Poskrobko (Ed.), Wpływ idei zrównoważonego rozwoju na politykę państwa i regionów, Tom I: Problemy ogólnopaństwowe i sektorowe (pp. 36-48). Białystok: Wydawnictwo Wyższej Szkoły Ekonomicznej w Białymstoku.

Fiedor, B. (2013). Normatywny charakter koncepcji trwałego rozwoju a potrzeba poszukiwania jej podstaw mikroekonomicznych. Handel wewnętrzny, Tom I, (listopad-grudzień), 7-20.

Ghosh, N., \& Goswami, A. (2014). Sustainability Science for Social, Economic, and Environmental Development. Hershey, PA: IGI Global. doi:10.4018/978-1-4666-4995-8.

Jäger, J. (2009). [online] Sustainability Science in Europe. Background Paper prepared for DG Research. Retrieved on November 20, 2014 from: <http://seri.at/wp-content/uploads/2009/ 11/Sustainability-Science-in-Europe.pdf>.

Konstytucja Rzeczypospolitej Polskiej z dnia 2 kwietnia 1997 r. (Dz.U. 1997 nr 78 poz. 483).

Levin, S.A., \& Clark, W.C. (Eds.) (2010). Toward Science of Sustainability. Center for International Development, Working Papers 196, John F. Kennedy School of Government, Harvard University.

Ministerstwo Administracji i Cyfryzacji (2013). Długookresowa Strategia Rozwoju Kraju "Polska 2030. Trzecia fala nowoczesności". Warszawa.

Ministerstwo Rozwoju Regionalnego (2012). Plan uporzqdkowania strategii rozwoju, Tekst uwzględniający dokonane w dniu 10 marca 2010 r., 30 kwietnia 2011 r. oraz 12 lipca 2012 r. reasumpcje decyzji Rady Ministrów z dnia 24 listopada 2009 r. Warszawa.

Ministerstwo Środowiska (1999). [online] Strategia Zrównoważonego Rozwoju Polski do 2025 roku. Retrieved on November 15, 2014 from: <http://www.access.zgwrp.org.pl/materialy/ dokumenty/StrategiaZrownowazonegoRozwojuPolski/index1.html>.

OECD (2001). The DAC Guidelines Strategies for Sustainable Development. International Development. Paris.

OECD (2006). Good Practices in the National Sustainable Development Strategies of OECD Countries. Sustainable Development Studies. Paris.

OECD (2012). OECD Environmental Outlook to 2050: The Consequences of Inaction. Paris.

Parris, T.M., \& Kates, R.W. (2003). Characterizing and measuring sustainable development. Annual Review of Environment and Resources, 28, 559-586.

Preisner, L., \& Pindór, T. (1999). Wskaźniki rozwoju społeczno-ekonomicznego stosowane przez UNDP. Problemy ekorozwoju, 1, 9-12.

Sekerka, B., Obrsalova, I., \& Bata, R. (2014). Analyse options for relationship between sustainability development indicators. WSEAS Transactions on Environment and Development, 10, 223-232.

Śleszyński, J. (2011). Indicators for sustainable development. In H. Rogall (Ed.), Jahrbuch Nachhaltige Ökonomie. Brennpunkt: "Wachstum" (pp. 279-288). Marburg: Metropolis. 
Śleszyński, J. (2013). Synthetic sustainable development indicators: past experience and guidelines. Research Papers of Wrocław University of Economics, 308, 144-164.

Sustainable Development Solutions Network (2014). Indicators and a monitoring framework for Sustainable Development Goals: Launching a data revolution for the SDGs. A report by the Leadership Council of the Sustainable Development Solutions Network. Revised working draft - November 25.

United Nations (1992). Agenda 21 - United Nations Conference on Environment \& Development Rio de Janerio, Brazil, 3 to 14 June 1992. Rio de Janerio: United Nations Division for Sustainable Development.

United Nations (2008). Measuring Sustainable Development. Report of the Joint UNECE/OECD/Eurostat Working Group on Statistics for Sustainable Development, New York and Geneva.

United Nations (2012). Report of the United Nations Conference on Sustainable Development. Rio de Janeiro, Brazil 20-22 June 2012. New York.

Urbaniec, M. (2011). Ausgewählte Instrumente für nachhaltige Entwicklung. In G. Banse, J. Janikowski, \& A. Kiepas (Eds.), Nachhaltige Entwicklung - transnational: Sichten und Erfahrungen aus Mitteleuropa (pp. 291-302). Berlin: Edition Sigma.

Urbaniec, M., \& Halavach, E. (2008). Wdrażanie rozwoju zrównoważonego: strategie i instrumenty. Częstochowa: Educator.

Ustawa z dnia 27 kwietnia 2001 r. Prawo ochrony środowiska (Dz.U. 2001 nr 62 poz. 627).

Ustawa z dnia 27 marca 2003 r. o planowaniu i zagospodarowaniu przestrzennym (Dz.U. $2003 \mathrm{nr}$ 80 poz. 717).

Ustawa z dnia 6 grudnia 2006 r. o zasadach prowadzenia polityki rozwoju (Dz.U. z 2006 r. Nr 227, poz. 1658).

World Commission on Environment and Development (1987). Our Common Future. Report of the World Commission on Environment and Development, Oxford: Oxford University Press. 


\section{Author}

\section{Maria Urbaniec}

Assistant Professor at the Department of Entrepreneurship and Innovation of the Cracow University of Economics (Poland).

\section{Correspondence to:}

Maria Urbaniec, PhD

Cracow University of Economics

Faculty of Economics and International Relations

Department of Entrepreneurship and Innovation

ul. Rakowicka 27, 31-510 Kraków, Poland

maria.urbaniec@uek.krakow.pl

\section{Copyright and License}

This article is published under the terms of the Creative Commons Attribution - NonCommercial - NoDerivs (CC BY-NC-ND 3.0) License http://creativecommons.org/licenses/by-nc-nd/3.0/ 